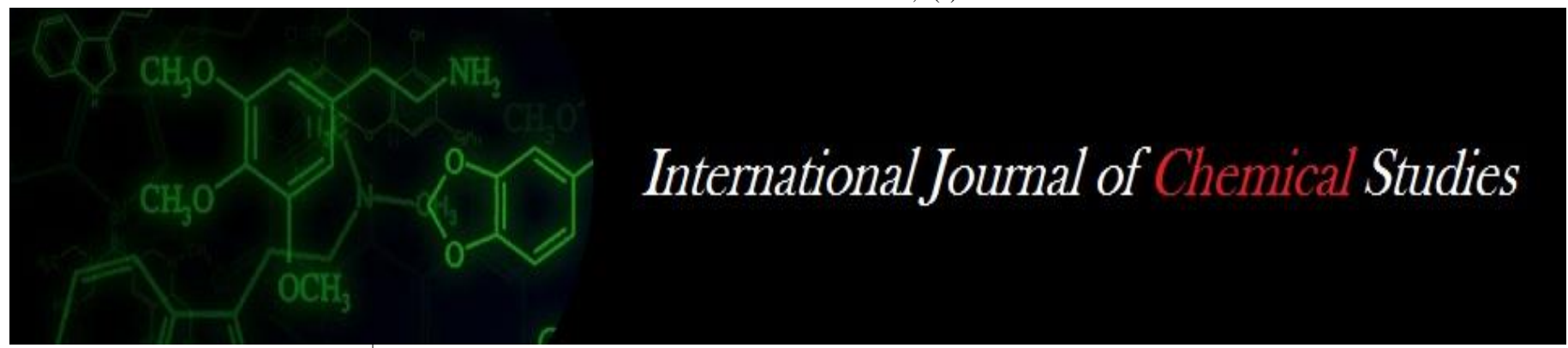

P-ISSN: 2349-8528

E-ISSN: 2321-4902

www.chemijournal.com

IJCS 2021; 9(1): 2217-2219

(C) 2021 IJCS

Received: 07-11-2020

Accepted: 18-12-2020

Lakshmidevamma TN

College of Horticulture, Bidar

UHS, Bagalkot, Karnataka,

India

\section{Jagadeesha RC}

College of Horticulture, Bidar UHS, Bagalkot, Karnataka,

India

Hanchinamani CN

College of Horticulture, Bidar UHS, Bagalkot, Karnataka,

India
Corresponding Author: Lakshmidevamma TN College of Horticulture, Bidar UHS, Bagalkot, Karnataka, India

\section{Genotypic, phenotypic correlation and path analysis studies in Chilli (Capsicum annuum)}

\author{
Lakshmidevamma TN, Jagadeesha RC and Hanchinamani CN
}

DOI: $\underline{\text { https://doi.org/10.22271/chemi.2021.v9.i1ae.11548 }}$

\begin{abstract}
Field experiment was conducted at the college of Horticulture, Bidar University of Horticultural Sciences, Bagalkot (Karnataka) to know the genotypic, phenotypic and Path association between ten yield and yield attributing characters in green chilli. Correlation coefficients indicated that fruit yield per plant was significant and positively correlated with number of fruits per plant and number of branches per plant. Incidence of leaf curl showed highly significant and negative correlation with yield per plant at both phenotypic (-0.606) and genotypic (-0.747) leavel.
\end{abstract}

Keywords: Chilli, genotypic correlation, phenotypic correlation

\section{Introduction}

Chilli (Capsicum annuum L.) important vegetable as well as spice crop. In India, there is no home which does not consume chilli either as green or dry. It finds a place in pharmaceuticals also. India is the major green chilli growing country in the world having an area of 140.04 thousand hectare with production of 1687.83 thousand tons. In India, Karnataka is the major growing state where area under green chilli is 43.66 thousand hectare and production is 596.13 thousand tons followed by Bihar of 39.49 thousand hectare and 478.1313 thousand ton (Anon., 2018) ${ }^{[2]}$. Maximum diversity can be noticed among different cultivars available in India and outside with respect to shape, size, yield, quality and other traits. Identification of a variety better suited for a particular region and its improvement is of immediate task to exploit its potential. The improvement can be brought out after confirming the association of most important character yield with other yield attributing characters. Hence, an experiment was conducted at College of Horticulture, Bidar to know the genotypic and phenotypic association between ten most important yield and yield attributing traits in green chilli.

\section{Materials and Methods}

Field experiment was conducted at the College of Horticulture, Bidar), University of Horticultural Sciences, Bagalkot (Karnataka) with forty five genotypes of chilli. The trial was laid out in randomized complete block design (RCBD) with two replications. Thirty days old seedlings were transplanted at spacing of $60 \mathrm{~cm} \times 45 \mathrm{~cm}$. All the recommended cultural practices were followed to raise good chilli crop (Anon., 2013) ${ }^{[1]}$. Five randomly selected plants in each experimental plot were used for recording observations on vegetative, yield and yield attributing parameters. The data was subjected to statistical analysis by adopting complete randomized block design (Panse and Sukhatme, 1967) ${ }^{[6]}$ and the phenotypic correlation coefficient and genotypic correlation coefficient were computed by using INDOSTAT software.

\section{Results and Discussion}

In the present investigation the relation of yield with yield attributing characters as well as among themselves was examined using genotypic and phenotypic correlation analysis. The genotypic correlation was higher than the phenotypic correlation indicating high heritable nature of characters. The growth and yield attributing characters like plant height $(0.486$ and 0.511 respectively), number of fruits per plant ( 0.798 and 0.800 respectively), and number of branches per plant ( 0.201 and 0.274 respectively) had highly significant positive correlation with yield per plant at phenotypic and genotypic level respectively (Table 1 and 2). Since, 
these associations of characters are in desirable direction indicating higher contribution of these characters towards yield. Similar results were also reported by Chaudhary et al., (2013) ${ }^{[3]}$, Vijay et al., (2015) ${ }^{[11]}$ and Srividya et al., (2017) ${ }^{[9]}$. Incidence of leaf curl showed highly significant and negative correlation with yield per plant at phenotypic (-0.606) and negative correlation at genotypic (-0.747) level. Similar results were reported by Ullah et al., (2011) ${ }^{[10]}$ and Chaudhary et al., (2013) ${ }^{[3]}$. The correlation coefficient would indicate only the relationship of independent variables with the dependent variable without specifying cause and effect. Using path coefficient analysis, it is possible to resolve the correlations, by subjecting the correlation co-efficient to path analysis for partitioning the correlation values into direct and indirect effect through alternate ways. The results showing the direct and indirect effect of various traits of chilli are presented in Table 3.

Days to maturity (0.431), Plant height (0.511), number of branches per plant (0.274) number of fruits per plant (0.800) have shown positive direct effect on yield per plant while, incidence of leaf curl $(-0.741)$ has shows negative direct effects on yield per plant study conform findings of Farhad et al., 2008; Sarkar et al., 2009; Kumar et al., 2012; Negi and Sharma, $2019^{[4,8,5,7]}$.

Table 1: Phenotypic correlation coefficients among yield attributing traits in chilli

\begin{tabular}{|c|c|c|c|c|c|c|c|c|c|c|c|}
\hline & $\begin{array}{c}\text { Days to } \\
\mathbf{5 0 \%} \\
\text { flowering }\end{array}$ & $\begin{array}{c}\text { Day to } \\
\text { Maturity }\end{array}$ & $\begin{array}{c}\text { Plant } \\
\text { height }\end{array}$ & $\begin{array}{c}\text { Number of } \\
\text { branches } \\
\text { per plant }\end{array}$ & $\begin{array}{c}\text { Number of } \\
\text { fruits per } \\
\text { plant }\end{array}$ & $\begin{array}{c}\text { Fruit } \\
\text { length }\end{array}$ & $\begin{array}{c}\text { Fruit } \\
\text { width }\end{array}$ & $\begin{array}{c}\text { Test } \\
\text { weight }\end{array}$ & $\begin{array}{c}\text { Incidence of } \\
\text { Leaf curl }\end{array}$ & $\begin{array}{c}\text { Yield per } \\
\text { plant }\end{array}$ \\
\hline Days to 50\% flowering & 1.000 & $0.941^{* *}$ & -0.004 & 0.0186 & -0.004 & 0.113 & -0.033 & 0.073 & 0.100 & -0.020 \\
\hline Day to Maturity & & 1.000 & -0.029 & 0.0253 & 0.0003 & 0.088 & -0.021 & 0.064 & 0.119 & -0.023 \\
\hline Plant height & & & 1.000 & $0.234^{*}$ & $0.395^{* *}$ & 0.039 & 0.009 & -0.139 & $-0.272^{*}$ & $0.486^{* *}$ \\
\hline Number of branches per plant & & & & 1.000 & $0.423^{* *}$ & -0.071 & $-0.217 *$ & $-0.268^{*}$ & $-0.223^{*}$ & $0.201^{*}$ \\
\hline Number of fruits per plant & & & & & 1.000 & 0.020 & -0.096 & $-0.313^{* *}$ & $-0.612^{* *}$ & $0.798^{* *}$ \\
\hline Fruit length & & & & & & 1.000 & 0.025 & 0.020 & -0.071 & $0.202^{*}$ \\
\hline Fruit width & & & & & & & 1.000 & 0.134 & -0.094 & 0.192 \\
\hline Test weight & & & & & & & & 1.000 & 0.106 & -0.041 \\
\hline Incidence of Leaf curl & & & & & & & & & 1.000 & $-0.606^{* *}$ \\
\hline Yield per plant & & & & & & & & & & & 1.000 \\
\hline
\end{tabular}

Table 2: Genotypic correlation coefficients among yield attributing traits in chilli

\begin{tabular}{|c|c|c|c|c|c|c|c|c|c|c|}
\hline & \begin{tabular}{|c|} 
Days to \\
$\mathbf{5 0 \%}$ \\
flowering \\
\end{tabular} & $\begin{array}{c}\text { Day to } \\
\text { Maturity }\end{array}$ & $\begin{array}{l}\text { Plant } \\
\text { height }\end{array}$ & \begin{tabular}{|c|} 
Number of \\
branches \\
per plant
\end{tabular} & $\begin{array}{c}\text { Number of } \\
\text { fruits per } \\
\text { plant }\end{array}$ & $\begin{array}{l}\text { Fruit } \\
\text { length }\end{array}$ & $\begin{array}{l}\text { Fruit } \\
\text { width }\end{array}$ & $\begin{array}{c}\text { Test } \\
\text { weight }\end{array}$ & \begin{tabular}{|c|} 
Incidence \\
of Leaf \\
curl
\end{tabular} & $\begin{array}{c}\text { Yield per } \\
\text { plant }\end{array}$ \\
\hline Days to $50 \%$ flowering & 1.000 & $0.968 * *$ & 0.004 & 0.008 & 0.011 & 0.155 & -0.037 & 0.074 & 0.130 & -0.006 \\
\hline Day to Maturity & & 1.000 & -0.045 & 0.004 & -0.007 & \begin{tabular}{|l|}
0.107 \\
\end{tabular} & -0.031 & 0.054 & 0.165 & -0.020 \\
\hline Plant height & & & 1.000 & $0.230^{*}$ & $0.410 * *$ & 0.026 & 0.002 & -0.134 & $-0.366 * *$ & $0.511 * *$ \\
\hline Number of branches per plant & & & & 1.000 & $0.534 * *$ & -0.096 & $-0.295 * *$ & $-0.312 * *$ & $-0.428 * *$ & $0.274 * *$ \\
\hline Number of fruits per plant & & & & & 1.000 & 0.011 & -0.124 & $-0.377 * *$ & $-0.743 * *$ & $0.800 * *$ \\
\hline Fruit length & & & & & & 1.000 & 0.015 & -0.005 & -0.114 & $0.216^{*}$ \\
\hline Fruit width & & & & & & & 1.000 & 0.131 & -0.103 & 0.193 \\
\hline Test weight & & & & & & & & 1.000 & 0.148 & -0.052 \\
\hline Incidence of Leaf curl & & & & & & & & & 1.000 & $-0.747 * *$ \\
\hline Yield per plant & & & & & & & & & & 1.000 \\
\hline
\end{tabular}

Table 3: Genotypic path co-efficient of different component characters on chilli yield per plant

\begin{tabular}{|c|c|c|c|c|c|c|c|c|c|c|}
\hline Traits & $\begin{array}{c}\text { Days to } 50 \% \\
\text { flowering }\end{array}$ & $\begin{array}{c}\text { Day to } \\
\text { Maturity }\end{array}$ & $\begin{array}{l}\text { Plant } \\
\text { height }\end{array}$ & $\begin{array}{c}\text { Number of } \\
\text { branches per } \\
\text { plant }\end{array}$ & $\begin{array}{c}\text { Number of } \\
\text { fruits per } \\
\text { plant }\end{array}$ & $\begin{array}{l}\text { Fruit } \\
\text { length }\end{array}$ & $\begin{array}{l}\text { Fruit } \\
\text { width }\end{array}$ & $\begin{array}{c}\text { Test } \\
\text { weight }\end{array}$ & $\begin{array}{l}\text { Incidence of } \\
\text { Leaf curl }\end{array}$ & $\begin{array}{l}\text { Yield per } \\
\text { plant (r) }\end{array}$ \\
\hline Days to $50 \%$ flowering & -0.442 & 0.400 & 0.001 & -0.001 & 0.009 & 0.032 & -0.008 & 0.019 & -0.015 & -0.006 \\
\hline Day to Maturity & 28 & 13 & (-0009 & 00 & -0.006 & 0.022 & -0.007 & 0.014 & & -0.020 \\
\hline Plant height & -0.002 & -0.019 & 0.208 & -0.020 & 0.331 & 0.005 & 0.001 & -0.034 & 0.041 & $0.511 * *$ \\
\hline Number of branches & -0.004 & 0.002 & 0.048 & -0.088 & 0.430 & -0.020 & -0.063 & -0.079 & 0.048 & $0.274 * *$ \\
\hline Number of fruits & -0.005 & -0.003 & 0.085 & -0.047 & 0.806 & 0.002 & -0.027 & -0.095 & 0.083 & $0.800 * *$ \\
\hline Fruit length & -0.069 & 0.044 & 0.005 & 0.008 & 0.009 & 0.204 & 0.003 & -0.001 & 0.013 & $0.216^{*}$ \\
\hline Fruit width & 0.016 & -0.013 & 0.001 & 0.026 & -0.100 & 0.003 & 0.215 & 0.033 & 0.012 & 0.193 \\
\hline Test weight & -0.033 & 0.022 & -0.028 & & & -0.001 & 0.028 & 0.253 & -0.017 & -0.052 \\
\hline Incidence of Leaf curl & -0.058 & 0.068 & -0.076 & 0.038 & -0.598 & -0.023 & -0.022 & 0.037 & -0.112 & $-0.747 * *$ \\
\hline
\end{tabular}

\section{References}

1. Anonymous. Improved cultivation practices of vegetables (Kannada), University of Horticultural Sciences, Bagalkot 2013, pp. 130-131.

2. Anonymous. Indian Horticultural Database 2018. http: //www. nhb. gov. in.

3. Choudhary BS, Samadia DK. Variability and character association in chilli land races and genotypes under arid environment. Indian J. Hort. 2013;61(2):132-136.
4. Farhad M, Hasanuzzaman M, Biswas BK, Azad AK, Arifuzzaman M. Reliability of yield contributing characters for improving yield potential in chilli (Capsicum annuum L.). Int. J. Sustain. Crop Prod 2008;3(3):30-38.

5. Kumar D, Rangare VB, Singh SBD. Genetic variability, heritability and correlation studies in chilli (Capsicum annuиm L.). Hort Flora Res Spectrum 2012;1:248-252. 
6. Panse VG, Sukhatme PV. The application of genetics to plant breeding. IV. The inheritance of quantitative characters and plant breeding. J. Genet 1957;40:283-302.

7. Paramjeet Singh Negi, Akhilesh Sharma. Studies on Variability, Correlation and Path Analysis in Red Ripe Chilli Genotypes. Int. J. Curr. Microbiol. App. Sci 2019;8(4):1604-1612.

8. Sarkar S, Murmu D, Chattopadhyay A, Hazra P. Genetic variability, correlation and path analysis of some morphological characters in chilli. J. Crop Weed 2009;5:162-166.

9. Srividya S, Kumar SR, Yasin GM. Association analysis in chilli genotypes for dry fruit yield. International J Hort 2017;7(7):47-53.

10. Ullah MZ, Hassan MJ, Saki AI, Rahman MA, Biswas PL. Association of correlation and cause-effect analysis among morphological traits in chili (Capsicum frutescens L.). International. J. Bio. Res 2011;10(6):19-24.

11. Vijaya HM, Gowda APM, Umesha K, Lingaiah HB, Nehru SD. Evaluation and correlation studies in chilli (Capsicum annuum L.) genotypes for quality parameters. Progressive Horticulture 2015;47(2):341-343. 